\title{
Long-term effects of 7-monohydroxyethylrutoside (monoHER) on DOX-induced cardiotoxicity in mice
}

\author{
Anna M. E. Bruynzeel • Suzanne Vormer-Bonne • \\ Aalt Bast • Hans W. M. Niessen • Wim J. F. van der Vijgh
}

Received: 26 September 2006 / Accepted: 28 November 2006 / Published online: 20 December 2006

(C) Springer-Verlag 2006

\begin{abstract}
Doxorubicin (DOX) is a potent antitumor agent for different types of cancer, but the cumulative, dose-related cardiotoxicity limits its clinical use. The incidence of abnormal cardiac function after treatment with DOX appears to increase with time. Therefore, late cardiotoxicity is-especially in young surviving patients - a major concern. The aim of this study was to evaluate in mice whether the semisynthetic flavonoid 7-monohydroxyethylrutoside (monoHER) also protected
\end{abstract}

This work was supported in part by grant VU-97-1525 from the Koningin Wilhelmina Foundation, Amsterdam, The Netherlands.

A. M. E. Bruynzeel $(\bowtie) \cdot$ S. Vormer-Bonne ·

W. J. F. van der Vijgh

Department of Medical Oncology,

VU University Medical Center, $1081 \mathrm{HV}$,

CCA-Building, room 1.38, De Boelelaan 1117,

Amsterdam, The Netherlands

e-mail: ame.bruynzeel@vumc.nl

H. W. M. Niessen

Department of Pathology,

VU University Medical Center,

1081 HV Amsterdam, The Netherlands

H. W. M. Niessen

ICaR-VU, VU University Medical Center,

1081 HV Amsterdam, The Netherlands

H. W. M. Niessen

Department of Cardiac Surgery,

VU University Medical Center,

1081 HV Amsterdam, The Netherlands

\section{A. Bast · W. J. F. van der Vijgh}

Department of Pharmacology and Toxicology,

Faculty of Medicine, University of Maastricht,

6200 MD Maastricht, The Netherlands against DOX-induced cardiotoxicity after a long period of follow-up. Four groups of $6 \mathrm{Balb} / \mathrm{c}$ mice were treated weekly during 6 weeks with saline, DOX alone $(4 \mathrm{mg} / \mathrm{kg}$ i.v.), DOX preceded by monoHER (500 mg/kg i.p.), or DOX preceded by monoHER followed by long-term weekly monoHER injections during the observation period of 6 months. Half of the mice treated with DOX only developed DOXinduced heart failure and died within 6 months of observation. Two mice co-treated with monoHER showed weight loss and shortness of breath, whereas one mouse was found dead in its cage known with weight loss. The group receiving DOX plus long-term repeated doses of monoHER started to lose weight. Five out of six mice in this group developed shortness of breath and died before the end of the study with symptoms of cardiac failure induced by DOX. Statistical comparison of the histological heart damage between the different experimental groups was not possible, because the animals died at different timepoints in the observation period and DOX-induced cardiotoxicity progressed with time. Nevertheless, it was clear that the initial cardioprotective effect of monoHER was not prolonged during the half-year observation period. It was even suggested that addition of repeated doses of monoHER tended to aggravate DOX-induced cardiotoxicity. It cannot be excluded that the dose and frequency of monoHER administration is crucial in obtaining an optimal antioxidant activity without a pro-oxidant activity of monoHER.

Keywords Doxorubicin - Cardiotoxicity .

MonoHER - Monohydroxyethylrutoside ·

Cardioprotection $\cdot$ Long-term follow-up 


\section{Introduction}

The clinical efficacy of the chemotherapeutic agent doxorubicin (DOX) is severely limited by its dose-limiting cardiotoxicity in patients with cancer $[9,13,16$, 20]. The most common hypothesis for the mechanism by which DOX induces cardiac damage includes the formation of free radicals $[8,26]$. Heart tissue is particularly susceptible to free radicals because the concentration of enzymes protecting against oxidative damage is lower than that in other tissues [9, 10].

Several clinical studies showed that the incidence of abnormal cardiac function after treatment with DOX appears to increase with time $[11,14,18]$. In survivors of childhood cancer, the incidence of cardiac abnormalities also increased with the length of follow-up [11, 14]. More than $65 \%$ of children with cancer achieve longterm survival and because many of these survivors will have received DOX or another anthracycline, late anthracycline cardiotoxicity is a major concern $[5,17]$.

The importance to minimize or completely prevent this severe side effect of DOX treatment is clear. In the past we have identified the cardioprotective properties of 7-monohydroxyethylrutoside (monoHER) against DOX-induced cardiotoxicity in mice [23, 24] without influencing the antitumor effect of DOX. Its cardioprotection is believed to result from protection against DOX-induced free radicals through radical scavenging and iron chelating properties of monoHER [6, 22]. The cardioprotective effect of monoHER was dose-dependent and a dose of $500 \mathrm{mg} / \mathrm{kg}$ monoHE, $1 \mathrm{~h}$ before DOX completely protected against DOX-induced cardiotoxicity [23]. In all previous studies the protective properties of monoHER were evaluated during a 6-week treatment period and 2 weeks thereafter. Because the incidence of ventricular dysfunction continues to increase with time it is important to know whether the cardioprotective effect of monoHER is still present after a long period of follow-up.

Therefore, the aim of the present study was to evaluate the cardioprotective effect of monoHER in DOXtreated mice during a period of 6 months. The morphological changes in the cardiac tissue were evaluated by microscopic examination.

\section{Materials and methods}

Chemicals

7-Monohydroxyethylrutoside (monoHER) was kindly provided by Novartis Consumer Health (Nyon,
Switzerland). The drug was formulated and dissolved as described before, giving a final concentration of $33 \mathrm{mg} / \mathrm{ml}$ [4]. Formulated DOX (Doxorubicin hydrochloride, $2 \mathrm{mg} / \mathrm{ml}$ ) was obtained from Pharmachemie B.V. (Haarlem, The Netherlands). Before injection, the content of the vial was dissolved in a sterile $0.9 \%$ $\mathrm{NaCl}$ solution to obtain a concentration of $1 \mathrm{mg} / \mathrm{ml}$.

Animals

Twenty-four male BALB/c mice (20-25 g) obtained from Harlan Nederland (Horst, The Netherlands) were kept in a light- and temperature-controlled room (21-22 ${ }^{\circ}$; humidity $\left.60-65 \%\right)$. The animals were fed a standard diet (Harlan Teklad) and allowed to eat and drink tap water ad libitum. The animals were allowed to adapt to the laboratory housing conditions for 2 weeks before starting the experiment.

Experimental design

The protocol was approved by the Ethics Committee for animal experiments of the Vrije Universiteit (Amsterdam, The Netherlands).

The mice received one of the following weekly doseschedules for 6 weeks:

Group I $(n=6) \quad 0.5 \mathrm{ml} \quad 0.9 \% \mathrm{NaCl}$ solution i.p., followed by $0.1 \mathrm{ml} 0.9 \% \mathrm{NaCl}$ solution i.v.

Group II $(n=6) \quad 0.5 \mathrm{ml} \quad 0.9 \% \mathrm{NaCl}$ solution i.p., followed by $4 \mathrm{mg} / \mathrm{kg}$ DOX i.v.

Group III $(n=6) \quad 500 \mathrm{mg} / \mathrm{kg}$ monoHER i.p., followed by $4 \mathrm{mg} / \mathrm{kg}$ DOX i.v. after $60 \mathrm{~min}$.

Group IV $(n=6) \quad 500 \mathrm{mg} / \mathrm{kg}$ monoHER i.p., followed by $4 \mathrm{mg} / \mathrm{kg}$ DOX i.v. after $60 \mathrm{~min}$. In addition the i.p. injection with $500 \mathrm{mg} / \mathrm{kg}$ monoHER was continued once every week during the observation period of 26 weeks.

DOX was administered via the tail vein. During treatment and the 26 weeks of observation thereafter, body weight was determined once a week as a measure of general toxicity. After this long period of observation or earlier when necessitated by the bad condition of an animal, the animals were sacrificed. The hearts were excised and the central part of both ventricles was cut into 5-mm-thick pieces of 2-3 mm, which were fixed in $4 \%$ phosphate buffered formaldehyde solution.

Histological analyses

After fixation in $4 \%$ phosphate buffered formaldehyde solution, the heart tissue was post fixed in $1 \%$ 
osmium tetroxide. The tissue was then dehydrated through a graded series of ethanol solutions of $70-95 \%$ and embedded in JB-4 Plus resin. Thereafter $0.5-3.0 \mu \mathrm{m}$-thick sections were cut with a glass knife. These semithin sections were examined by light microscopy and the myocardial damage was evaluated according to Billingham [1]. For this purpose, the percentage of cardiac myocytes that had been damaged was determined. Cardiac myocytes with more than two vacuoles and/or loss of myofibrils were considered to be damaged. The scoring area was measured using a commercially available interactive video overlay based measuring system (Q-Prodit, Leica, Cambridge, UK) [25]. For each mouse the number of aberrant myocytes per $\mathrm{mm}^{2}$ was scored.

\section{Results}

Effect on behavior and condition of the mice

The mice of the saline group appeared lively throughout the whole period of the study and no behavioral changes were observed. Their weight increased during these months.

After the first 8 weeks of treatment, behavior of the animals appeared normal in all treatment groups. No signs of decreased activity and no significant differences in weight gain between the groups were observed, indicating low general toxicity. Table 1 illustrates characteristics of the mice per experimental group during the whole study. During the observation period of 26 weeks, nine mice from the groups treated with DOX were sacrificed. All of them had shortness of breath, a decreased activity, loss of appetite and finally as a consequence loss of weight of more than $10 \%$. Their fur looked bad and the animals arched their back. These symptoms were indicated as clinical signs of congestive heart failure (CHF). Three mice were found dead in their cage during the observation period. Two of them already showed loss of weight, but the third mouse died unexpectedly. The remaining animals in group II and III survived without problems (no signs of decreased activity or significant differences in weight gain) until the end of the study. Five out of six animals of the fourth group treated with monoHER once every week during the observation period ended up in a bad condition, showing the earlier described features. Therefore, the mice were sacrificed, or died before the end of the study. Mouse IV-21 was not in a bad condition, but died unexpectedly.
Symptoms of CHF observed in sacrificed and dead animals

Nine mice from group II-IV were sacrificed before the end of the study. Eight of them were evaluable. The data of animal IV-19 got lost. All nine mice showed loss of weight progressing rapidly during the last days before their sacrifice. During autopsy, it was clear that all animals were starved. The heart was enlarged in the eight mice and some of them had also some pleural fluid, which is indicative of CHF. Of the three animals found dead in their cage, one (IV-20) showed an enlarged heart. No signs of cardiac failure or another cause of death was found during autopsy in the other two mice, but one of them (III-13) showed signs of starvation.

Microscopic evaluation of the heart tissue of all animals

A number of animals died at different times in the follow-up period. Because DOX-induced cardiotoxicity is progressing with time, a statistical comparison of myocardial damage in the mice of the four experimental groups was not feasible anymore. Nevertheless, the percentage of damaged cardiac myocytes was evaluated. Cardiac myocytes with more than two vacuoles and/or loss of myofibrils were considered damaged. An overview of the aberrant cardiac myocytes $/ \mathrm{mm}^{2}$ in the animals of the experimental groups is also presented in Table 1. Overall, heart tissue of animals treated with saline had a low score. The difference between the score of the saline-treated mice and the animals of the other experimental groups was remarkable, whereas between the three groups treated with DOX with or without monoHER hardly any difference was observed. Besides the (almost) absence of vacuolar degeneration in the cardiac myocytes of the mice treated with saline, their cardiac cells also showed a higher concentration of myofibrils in comparison to the other experimental groups.

\section{Discussion}

Several studies showed that the long-term effect of DOX on cardiac tissue may progress in time to more severe myocardial injury resulting in cardiomyopathy or even CHF $[11,18]$. Therefore, advances in longterm survival achieved over the last two decades for e.g.; acute leukaemia in childhood necessitate obtaining favorable long-term effects of DOX-containing anticancer treatment [12]. Thus, it is desirable to 
Table 1 Characteristics of the mice per experimental group
Groups: I saline, II DOX alone, III DOX-monoHER, IV DOX-monoHER + monoHER once every week

$Y$ yes, $U$ unknown, information was lost, Score $/ \mathrm{mm}^{2}$ abnormal cardiac myocytes/ $\mathrm{mm}^{2}$ scored according to Billingham, $N$ no material available, $N E$ tissue not suitable for evaluation

${ }^{a}$ Weeks from the start of the observation period

\begin{tabular}{lllllll}
\hline $\begin{array}{l}\text { Mouse } \\
\text { (Group, \#) }\end{array}$ & $\begin{array}{l}\text { Time of } \\
\text { death } \\
(\text { weeks) }\end{array}$ & $\begin{array}{l}\text { Sacrificed } \\
(\mathrm{S}) / \text { death (D) }\end{array}$ & $\begin{array}{l}\text { Pleural } \\
\text { fluid } \\
(\mathrm{Y} / \mathrm{U})\end{array}$ & $\begin{array}{l}\text { Enlarged } \\
\text { heart } \\
(\mathrm{Y} / \mathrm{U})\end{array}$ & $\begin{array}{l}\text { Weight } \\
\text { Loss }\end{array}$ & Score $/ \mathrm{mm}^{2}$ \\
\hline
\end{tabular}
1

$\begin{array}{ll}2 & \mathbf{5 . 5} \\ 3 & 0.4\end{array}$

$4+2.2$

5 -

6

II

7

8

9

10

11

12

III

13

14

15

16

17

18

IV

19

20

21

22

23

24

10

$$
17
$$

24

17

21

18

S

S

$$
\begin{aligned}
& \mathrm{S} \\
& \mathrm{S}
\end{aligned}
$$

D
S

$$
\text { S }
$$

10
17
12
13
17
18
10

$\mathbf{5 . 5}$
0.
2.
1.5
1.4

Y

Y $\quad$ Y 16.8

25.9

15.6

24.8

18.8

$\mathrm{N}$

5.3

5.8

14.5

23.6

19.8

11.7

$\mathrm{N}$

12.5

$\mathrm{N}$

16.7

16.1

$\mathrm{NE}$ dispose of a compound giving long-term cardioprotection. MonoHER, a flavonoid with proven cardioprotecting properties $[4,23,24]$, and at present in a clinical phase II study, is expected to be such a compound.

The results of this study corroborate that monoHER given $1 \mathrm{~h}$ before DOX is protecting in vivo against DOX-induced cardiotoxicity within the first 8 weeks of treatment. Its cardioprotective effect is present for a longer period of time thereafter, but towards the end of 26 weeks of observation, the cardioprotection by monoHER is not present anymore and toxicity becomes comparable to that in DOX-treated animals. Continuation of weekly injections of monoHER (after DOX administration was ended) during the observation period even seems to aggravate the development of DOX-induced cardiotoxicity.

At the end of the study no difference in survival was observed between the mice treated with DOX alone and the animals treated with DOX-monoHER (group III), while the mice treated with monoHER once every week during the observation period even showed a decreased survival rate in comparison to the DOX-treated mice.

It is known however that flavonoids which can act as antioxidants, may display pro-oxidant action at higher doses [3, 15, 21] and/or when administered for an extended period of time [3]. One of the reasons for this change may be that compounds such as flavonoids and carotenoids which act as effective scavengers of reactive oxygen species, may themselves become reactive oxidation products [2, 3]. These secondary formed toxic products may interact with lipids, proteins and DNA giving rise to (pro-oxidant) cytotoxic as well as genotoxic effects.

Also, Boots et al. [2] showed that during its antioxidant activity quercetin becomes oxidized. This oxidized form is toxic since it reacts with for example the thiol glutathione (GSH), which results in a decreased amount of this cellular antioxidant.

Because of these properties, it may be that monoHER - being a structural analog of quercetin-was administered at a too high dose in the animals receiving monoHER just before DOX (group III) and especially in the animals receiving monoHER also once every week during the observation period (group IV). Therefore, it could be that the created overdose of the antioxidant monoHER started to behave as a prooxidant as shown for other flavonoids before [7, 15, 19, 21]. Another possible explanation may be that monoHER becomes a reactive oxidation product and thus 
depletes the already small amount of cardiac antioxidants.

The physical problems in the mice treated with monoHER every week (group IV) developed earlier and were more severe in comparison to the mice treated with DOX-monoHER (group III). This seems to underline the concentration-dependent pro-oxidative properties of monoHER. The right balance between the dose of monoHER and its anti- and prooxidant properties has not been established yet. This will play a key role in the further development of monoHER as a cardioprotector.

During microscopic evaluation of the cardiac damage we observed that the cardiac cells of mice treated with saline showed a higher density of myofibrils than the surviving animals treated with DOX either with or without monoHER. This observation-besides the morphological changes in the cardiac tissues which are included in the Billingham score (vacuolar degeneration, loss of myofibrils) - seems characteristic for longterm DOX-induced cardiac damage, because it was not seen in heart tissue of DOX-treated mice after a short observation time.

The present study indicates that the dose of monoHER may be crucial in providing an optimal anti-oxidant effect without a pro-oxidant effect, thus obtaining the desired long-term cardioprotective effect. These aspects have to be elucidated in more detail.

Acknowledgments We wish to thank Paula Mul and Caroline Erkelens from the Clinical Animal laboratory and Jan Fritz from the Department of Pathology of the Vrije Universiteit, Amsterdam, The Netherlands, for their excellent assistance.

\section{References}

1. Billingham ME, Mason JW, Bristow MR, Daniels JR (1978) Anthracycline cardiomyopathy monitored by morphologic changes. Cancer Treat Rep 62(6):865-872

2. Boots AW, Balk JM, Bast A, Haenen GRMM (2005) The reversibility of the glutathionyl-quercetin adduct spreads oxidized quercetin-induced toxicity. Biochem Biophys Res Comm 338:923-929

3. Breinholt VM, Mølck AM, Svendsen GW, Daneshvar B, Vinggaard AM, Poulsen M, Dragsted LO (2003) Effects of dietary antioxidants and 2-amino-3-methylimidazo[4,5-f]quinoline (IQ) on preneoplastic lesions and on oxidative damage, hormonal status, and detoxification capacity in the rat. Food Chem Toxicol 41:1315-1323

4. Bruynzeel AME, Mul PNN, Berkhof J, Bast A, Niessen HWM, van der Vijgh WJF (2006) The influence of the timeinterval between monoHER and doxorubicin administration on the protection against doxorubicin-induced cardiotoxicity in mice. Cancer Chemother Pharmacol 58(5):699-702

5. Grenier MA, Lipshultz SE (1998) Epidemiology of anthracyclin cardiotoxicity in children and adults. Semin Oncol 25(suppl 10):72-85
6. Haenen GRMM, Jansen FP, Bast A (1993) The antioxidant properties of five O- (beta-hydroxyethyl) rutosides of the flavonoid mixture Venoruton. Phlebology Suppl 1:10-17

7. Hibatallah J, Carduner C, Poelman MC (1999) In-vivo and invitro assessment of free radical scavenger activity of Ginkgo flavone glycosides at high concentration. J Pharm Pharmacol 51(12):1435-1440

8. Horenstein MS, Vander Heide RS, L'Ecuyer TJ (2000) Molecular basis of anthracycline-induced cardiotoxicity and its prevention. Mol Genet Metabol 71:436-444

9. Hrdina R, Gersl V, Klimtova I, Simunek T, Machackova J, Adamcova M (2000) Anthracycline-induced cardiotoxicity. Acta Medica 43(3):75-82

10. Iarussi D, Indolfi P, Galderisi M, Bossone E (2000) Cardiac toxicity after anthracycline chemotherapy in childhood. Herz 25(7):676-688

11. Kremer LCM, van Dalen EC, Offringa M, Ottenkamp J, Voute PA (2001) Anthracyclin-induced clinical heart failure in a cohort of 607 children: long-term follow-up study. J Clin Oncol 19:191-196

12. Langebrake C, Reinhardt D, Ritter J (2002) Minimising the long-term adverse effects of childhood leukaemia therapy. Drug Saf 25(15):1057-1077

13. Lefrak EA, Pitha J, Rosenheim S, Gottlieb JA (1973) A clinicopathologic analysis of adriamycin cardiotoxicity. Cancer 32:302-314

14. Lipshultz SE, Colan SD, Gelber RD, Perez-Atayde AR, Sallan SE, Sanders SP (1991) Late cardiac effects of doxorubicin therapy for acute lymphoblastic leukaemia in childhood. N Eng J Med 324:808-815

15. Niering P, Michels G, Wätjen W, Ohler S, Steffan B, Chovolou Y et al. (2005) Protective and detrimental effects of kaempferol in rat H4IIE cells: implication of oxidative stress and apoptosis. Toxicol Appl Pharmacol 209:114-122

16. Singal PK, Iliskovic N (1998) Doxorubicin-induced cardiomyopathy. New Eng J Med 339(13):900-904

17. Sorensen K, Levitt GA, Bull C, Dorup I, Sullivan ID (2003) Late anthracyclin cardiotoxicity after childhood cancer. Cancer 97(8):1991-1998

18. Steinherz LJ, Steinherz PG, Tan CTC, Heller G, Murphy L (2001) Cardiac toxicity 4 to 20 years after completing anthracyclin therapy. JAMA 266(12):1672-1677

19. Sugihara N, Arakawa T, Ohnishi M, Furuno K (1999) Antiand pro-oxidative effects of flavonoids on metal-induced lipid hydroperoxide-dependent lipid peroxidation in cultured hepatocytes loaded with alpha-linolenic acid. Free Radic Biol Med 27(11-12):1313-1323

20. Swain SM, Whaley FS, Ewer MS (2003) Congestive heart failure in patients treated with doxorubicin. Cancer 97(11):28692879

21. Thomson AR, Mortensen A, Breinholt VM, Lindecrona RH, Penalvo JL, Sorensen IK (2005). Influence of Prevastein, an isoflavone-rich soy product, on mammary gland development and tumorigenesis in Tg.NK (MMTV/c-neu) mice. Nutr Cancer 52(2):176-188

22. Van Acker SABE, Towart R, Husken BCP, de Jong J, van der Vijgh WJF, Bast A (1993) The protective effect of Venoruton and its constituents on acute doxorubicin-induced cardiotoxicity. Phlebology Suppl 1:31-32

23. Van Acker SABE, Boven E, Kuiper K, van den Berg DJ, Grimbergen JA, Kramer K, Bast A, van der Vijgh WJF (1997) Monohydroxyethylrutoside, a dose-dependent cardioprotective agent, does not affect the antitumor activity of doxorubicin. Clin Cancer Res 3(10):1747-1754

24. Van Acker FAA, van Acker SABE, Kramer K, Haenen GRMM, Bast A, van der Vijgh WJF (2000) 7-monohydroxy- 
ethylrutoside protects against chronic doxorubicin-induced cardiotoxicity when administered only once per week. Clin Cancer Res 6(4):1337-1341

25. Vermeulen EG, Niessen HW, Bogels M, Stehouwer CD, Rauwerda JA, v Hinsbergh VW (2001) Decreased smooth muscle cell/extracellular matrix ratio of femoral artery in pa- tients with atherosclerosis and hyperhomocysteinemia. Arterioscler Thromb Vasc Biol 21:573-577

26. Xu MF, Tang PL, Oian ZM, Ashraf M (2001) Effects by doxorubicin on the myocardium are mediated by oxygen free radicals. Life Sci 68(8):889-901 